\title{
EMM of effective management of the integrated transportation and logistics system
}

\author{
Lochinbek F. Amirov ${ }^{1}$, Javlonbek S. Fayzullaev ${ }^{1}$, Hasan Sh. Rahimov ${ }^{1}$, and Nargiza T. \\ Shayusupova ${ }^{1, *}$ \\ ${ }^{1}$ Tashkent State University of Economics, 49, Uzbekistan str., 100003, Tashkent, Uzbekistan
}

\begin{abstract}
The authors chose the topic of an economic and mathematical model of effective management of an integrated transport and logical system, due to the relevance of the topic throughout the world and in all areas of activity. Effective integration is possible if it is based on the methodological principles of the concept of integrated logistics, when the economic interests of subjects and objects of the transport-logical system are coordinated while ensuring the implementation of the strategy and goals of the functioning of the system as a whole. The object of the research is the JSC "Uzbek Railways" of the Republic of Uzbekistan. The research priority is transport and logistics management. During the research, difficulties emerged that have created multivariance. The article presents modern methods of managing the transport and logistics system, the classification of modern methods of management concepts that make up the theoretical and methodological foundations of the integrated management of the transport and logistics system, the efficiency of delivery times for options $\mathrm{A}, \mathrm{B}, \mathrm{C}, \mathrm{D}$ and the economic efficiency of managing the transport and logistics system. Transport and logistics models are considered in economics as a business concept, having calculated the best option, you can optimize the economic process. In the conclusion, recommendations are given on the use of a mathematical model, short-term and long-term strategies for effective management of the transport and logistics system are given.
\end{abstract}

\section{Introduction}

The importance of transport and logistics infrastructure in the ongoing processes of globalization and integration is growing. According to the World Bank, the share of world transport services in GDP is 4.3 trillion. US dollars (6.9\%) and amounted to 110 billion rubles. tons of cargo and 1 trillion. More than 100 million passengers were transported, the number of employees in the transport infrastructure is 100 million. constitutes a personality [1]. The development of these sectors is carried out by the global transport and logistics system. The effective organization of management processes in the logistics system for the delivery of goods will save from $30 \%$ to $60 \%$ of material resources, as well as reduce the

\footnotetext{
*Corresponding author: indira91@inbox.ru
} 
transport and logistics costs of enterprises using the services of rail transport by about 30 $35 \%$.

Large-scale and targeted program measures are being taken to accelerate the qualitative development of the transport and logistics sectors as an important sector of the country's economy and an important factor in integrating the national economy into the world economy. In this regard, the launch of the Hairaton-Mazari-Sharif and Angren-Pop railways and the creation of logistics centers in the country led not only to an increase in domestic traffic, but also to an improvement in transit opportunities in Uzbekistan. The strategy of actions in five priority areas of development of the Republic of Uzbekistan for 2017-2021 identified important tasks to "strengthen competition between national transport and logistics companies" [2]. The effective implementation of these tasks requires an increase in the management efficiency of the integrated transport and logistics system in our country.

\section{Methods}

Effective management of an integrated transport and logistics system should be based on the principles of scientific validity, efficiency, optimization, complexity, flexibility, and purposefulness. Given the widespread application of the listed principles in modern science, we did not consider it necessary to clarify their content in this study. Classification of modern conceptual management methods that form the theoretical and methodological basis for managing an integrated transport and logistics system (table 1).

Table 1. Classification of conceptual methods of modern management that make up the theoretical and methodological foundations for managing an integrated transport and logistics system.

\begin{tabular}{|l|ll|}
\hline \multicolumn{1}{|c|}{$\begin{array}{c}\text { Management } \\
\text { concepts }\end{array}$} & \multicolumn{2}{|c|}{ Methods used in the management of integrated transport and } \\
logistics systems
\end{tabular}




\begin{tabular}{|l|ll|}
\hline & - & Analysis of ABC and XYZ. \\
\hline \multirow{4}{*}{ Strategic management } & - & internal and external environmental monitoring; \\
& - & SWOT analysis; \\
& - & strategic matrices \\
& processes; \\
& - & balanced scorecard; \\
\hline \multirow{3}{*}{ Operational guidance } & - & Model of the life cycle of transport and logistics services. \\
\hline & - & accounting and standardization of transport and logistics \\
& - & standardization of reserves; \\
\hline
\end{tabular}

It should be noted that the system and process approaches, conceptual rules of management, to this day serve as the basis for all of the listed concepts and theories of management. The methods, models and tools developed within these approaches are applied in various areas of management. [3.4]

\section{Result}

There is a need for deep structural changes in the world transport market based on modern logistics approaches. Today, as domestic and foreign experience shows, there is a need to create a unified transport system with a unified control center, as well as an integrated control center - from competitive to multimodal transport. Delivery times by type of transport are determined by the formulas given in Table 2 .

Table 2. Formulas for calculating the delivery of goods by type of transport.

\begin{tabular}{|c|c|c|}
\hline $\begin{array}{c}\text { Transport } \\
\text { type }\end{array}$ & Calculating the timing of the formula delivery \\
\hline Railway & $\mathrm{T}_{r}=\mathrm{T}_{t s}+L / V_{y}^{j}+t_{a d d}^{j} ; \quad T_{\mathrm{M}}+L / c o m$ & $(1)$ \\
\hline Pipe & $V_{c o m}=\frac{l}{\frac{l}{V_{d a y}}+\frac{2 \alpha D_{r}}{\mathrm{M}}+t_{a d d}^{\mathrm{M}}}$ & \\
\hline Air transport & $\mathrm{T}_{a t}=t_{t s}+\frac{l}{V_{\mathrm{H}}^{p}}+t_{a d d}^{p}$ & $(2)$ \\
\hline Vehicle & $\mathrm{T}_{v}=t_{t s}+\frac{l}{V_{o s}}$ & \\
\hline
\end{tabular}

Here:

$t_{t s}-$ time spent on commissioning, days. (k);

$l \quad$ - transportation distance, $\mathrm{km}$;

$V_{y}^{j}, V_{H}^{p}-$ norm of distance traveled by vehicles per day, $\mathrm{km}$;

$t_{\text {add }}^{j}, t_{\text {add }}^{M}, t_{\text {add }}^{p}$ - time, days spent on additional operations on rail, road and air transport;

$V_{o s}$ - operating speed, $\mathrm{km} / \mathrm{s}$;

$V_{\text {com }}$ - commercial speed, $\mathrm{km} /$ day;

$V_{\text {day }}$ - working speed of vehicles in this corridor, $\mathrm{km} /$ day; 
$\alpha$ - load capacity utilization factor;

$D_{r}$ - carrying capacity of wagons, railways;

$M$ - average daily rate of additional operations at the port of departure and arrival of cargo, $\mathrm{t} /$ day;

$t-$ time, days required to collect, store and send the goods.

For the organization of integrated transport and logistics activities, it is necessary to first study the characteristics of a single transport system, which includes rail, air and road transport[5]. Depending on the management strategy and tasks of the enterprise that carries out transport and logistics operations, the optimal modes of transport for cargo delivery are selected. It takes into account the technical and economic characteristics of transport modes, their capabilities and disadvantages, which determine their rational use, taking into account costs and management indicators. When choosing a delivery method, the shipper will have to work according to many criteria. These criteria are based on a five-point scale. In this case, "1" is the highest score, " $5 "$ is the lowest score (Table 3).

Table 3. Assessment of various modes of transport by the main factors affecting the choice of mode of transport (on a 5-point scale).

\begin{tabular}{|c|c|c|c|c|c|}
\hline $\begin{array}{c}\text { Modes of } \\
\text { transport }\end{array}$ & $\begin{array}{c}\text { Speed } \\
\text { delivery } \\
\text { time) }\end{array}$ & $\begin{array}{c}\text { Reliability } \\
\text { (schedule } \\
\text { compliance) }\end{array}$ & $\begin{array}{c}\text { Cargo } \\
\text { transport } \\
\text { capability }\end{array}$ & $\begin{array}{c}\text { Number of } \\
\text { geographic points } \\
\text { served }\end{array}$ & $\begin{array}{c}\text { Cost per } \\
\text { tonne-km } \\
\text { (price) }\end{array}$ \\
\hline Railway & 3 & 4 & 2 & 2 & 3 \\
\hline Water & 4 & 5 & 1 & 4 & 1 \\
\hline Vehicle & 2 & 2 & 3 & 1 & 4 \\
\hline Pipe & 5 & 1 & 5 & 5 & 2 \\
\hline Weather & 1 & 3 & 4 & 3 & 5 \\
\hline
\end{tabular}

In recent years, the volume of transit cargo transported by rail in our country has decreased by $6 \%$ over the past six years. This situation is explained by the lack of entrepreneurial skills in professional transport and the inadequacy of the control system. Therefore, in our study, we proposed an econometric model that represents a direct relationship between the railway transport system and the country's GDP (Table 4). The model was developed using data from 2007-2017. And it was implemented using the Eviews 9.0 computer program (Table 4).

Table 4. Main indicators of JSC "Uzbek Railways" in 2007-2017 [6].

\begin{tabular}{|c|c|c|c|c|}
\hline Year & $\begin{array}{c}\text { GDP. } \\
\text { USD } \\
\text { million }\end{array}$ & $\begin{array}{c}\text { The volume of } \\
\text { transit traffic by rail, } \\
\text { million tons }\end{array}$ & $\begin{array}{c}\text { Investments in } \\
\text { transportation and storage } \\
\text { systems, USD million }\end{array}$ & $\begin{array}{c}\text { Transportation } \\
\text { volume by rail, } \\
\text { million tons }\end{array}$ \\
\hline $\mathbf{2 0 0 7}$ & 22310 & 9.117 & 181.76 & 58 \\
\hline $\mathbf{2 0 0 8}$ & 29550 & 9.758 & 327.51 & 62.9 \\
\hline $\mathbf{2 0 0 9}$ & 33690 & 10.444 & 597.46 & 65.6 \\
\hline $\mathbf{2 0 1 0}$ & 39330 & 8.38 & 560.66 & 56.9 \\
\hline $\mathbf{2 0 1 1}$ & 45920 & 11.221 & 415.25 & 59.6 \\
\hline $\mathbf{2 0 1 2}$ & 51820 & 11.984 & 448.04 & 61.5 \\
\hline $\mathbf{2 0 1 3}$ & 57690 & 8.15 & 519.87 & 63.7 \\
\hline $\mathbf{2 0 1 4}$ & 63070 & 7.881 & 454.07 & 65.7 \\
\hline $\mathbf{2 0 1 5}$ & 66900 & 7.602 & 357.43 & 67.2 \\
\hline $\mathbf{2 0 1 6}$ & 67220 & 7.771 & 478.89 & 67.6 \\
\hline $\mathbf{2 0 1 7}$ & 72463.16 & 7.108 & 394.21 & 68.1 \\
\hline
\end{tabular}


The correlation matrix represents the values of the correlation coefficient ( $\rho$ ) for all possible pairs of analyzed variables (table 5).

$$
\rho=\operatorname{corr}(X, Y)=\frac{\sum_{i=1}^{n}\left(x_{i}-\bar{x}\right)\left(y_{i}-\bar{y}\right)}{\sqrt{\sum_{i=1}^{n}\left(x_{i}-\bar{x}\right)^{2} \sum_{i=1}^{n}\left(y_{i}-\bar{y}\right)^{2}}}=\frac{\overline{x y}-\bar{x} \bar{y}}{\sigma_{x} \sigma_{y}}
$$

Here:

$x$ - Variable factor;

$y$ - Variable value;

Table 5. Correlation matrix.

\begin{tabular}{|c|c|c|c|c|}
\hline \multicolumn{2}{|c|}{ Correlation } & & & \\
\hline t-Statistics & $\mathbf{Y}$ & $\mathbf{X 3}$ & $\mathbf{X 2}$ & $\mathbf{X 1}$ \\
\hline Probability & 1.000000 & & & \\
\hline Y & $\mathbf{0 . 5 5 6 8 0 8}$ & 0.482738 & 1.000000 & \\
\hline t-Statistics & 5.766443 & 4.741758 & ----- & \\
\hline Probability & 0.0000 & 0.0000 & ---- & \\
\hline X2 & $\mathbf{0 . 6 7 4 4 7 7}$ & 0.568889 & 0.564900 & 0.040088 \\
\hline t-Statistics & 7.858728 & 5.950482 & 5.889109 & 0.345124 \\
\hline Probability & 0.0000 & 0.0000 & 0.0000 & 0.7310 \\
\hline X1 & $\mathbf{0 . 7 8 6 7 3 4}$ & 0.695302 & 0.507837 & -0.009704 \\
\hline t-Statistics & 10.96359 & 8.322061 & 5.071180 & -0.083485 \\
\hline Probability & 0.0000 & 0.0000 & 0.0000 & 0.9337 \\
\hline
\end{tabular}

The factors studied are highly correlated with GDP. There is no interdependence, i.e. no multicollinearity. The linear regression equation was constructed using the coefficients obtained on the basis of the correlation matrix (table 6).

Table 6. Results of the regression model in the framework of the interaction of indicators of railway transport.

\begin{tabular}{|c|c|l|c|c|}
\hline Variable & Coefficient & Standard error & t-Statistics & Probability \\
\hline X3 & 109.12 & 15.95 & 6.12 & 0.0960 \\
\hline X2 & 1081.24 & 112.08 & 8.45 & 0.0061 \\
\hline C & 4327.15 & 120.35 & 9.65 & 0.0000 \\
\hline R Squared & -80329.01 & 0.06 & -4.98 & 0.0039 \\
\hline Aligned R squared & 0.941245 & Average of dependent variables & 20.32182 \\
\hline Standard error of regression & 0.941263 & $\begin{array}{l}\text { Standard deviation of the } \\
\text { dependent variable }\end{array}$ & 21.35058 \\
\hline Residual sum of squares & 1124.94 & Akaike Information Criteria & 7.752809 \\
\hline $\begin{array}{c}\text { Closeness to logarithmic } \\
\text { reality }\end{array}$ & -14589635 & Schwarz criterion & 7.936815 \\
\hline F-Statistics & 343.99 & Hannah-Quinn's criterion & 7.826347 \\
\hline Probability (F-Statistics) & 0.000000 & Darbin Watson statistics & 1.827987 \\
\hline
\end{tabular}

The optimal model was determined based on the linear regression equation:

$$
\mathrm{Y}=-80329.01+4327.15 * \mathrm{X} 1+1081.24 * \mathrm{X} 2+109.12 * \mathrm{X} 3
$$

Here,

$Y$ - Gross domestic product,

$X 1$ - volume of transit by rail;

$X 2$ - volume of investments in the transportation and storage system;

$X 3$ - volume of cargo transported by rail. 
The coefficient of determination (definition, formula and their interpretation). Conclusions on the case. Coefficient of determination in multivariate regression - the value of R2 denotes the part of the variable $\mathrm{Y}$, which can be explained using the regression equation found using the predicted variables. [7,8]

$$
R^{2}=\frac{\sum_{i=1}^{n}\left(\hat{y}_{i}-\bar{y}\right)^{2}}{\sum_{i=1}^{n}\left(y_{i}-\bar{y}\right)^{2}}=1-\frac{\sum_{i=1}^{n}\left(y_{i}-\hat{y}_{i}\right)^{2}}{\sum_{i=1}^{n}\left(y_{i}-\bar{y}\right)^{2}}=0.941
$$

It can be seen from the calculation model that, while other factors remain the same, the volume of transit cargo transported by rail will increase by $10 \%$, GDP by $13 \%$, and freight traffic by rail will increase by $1.164 \%$.

Thus, based on the above considerations, slow progress in the management of an integrated transport and logistics system is due to the following problems [9, 10]:

-insufficient container capacity;

-high transportation costs by rail;

-Lack of development of logistics service providers of 3PL and 4PL levels;

-About $60 \%$ of the cars have been in operation for $20-30$ years, $13 \%$ - more than 30 years;

-In international transportation, $1.5 \%$ of refrigerated cars $(15-20 \%$ of demand) are involved, which is $4 \%$ of carriages;

-Lack of a unified management mechanism for the transport and logistics system;

-The current mechanism for coordinating the transport and logistics system does not work;

-Lack of systematization of methods of general management of the transport and logistics system;

-In 2017 , the age of $68 \%$ of trucks involved in international transport was 15-20 years, and the age of $10 \%$ was $20-30$ years;

-The share of container traffic in international traffic is $7-8 \%$ (in the EU - 14\%, in China $-51 \%)$;

-More than $70 \%$ of the country's highways do not provide optimal speed;

-About $30 \%$ of the fixed assets of the warehouse are physically and morally obsolete;

-The level of mechanization of loading and unloading operations is $20-30 \%$.

\section{Discussion}

One of the most important aspects in providing well-defined transport and logistics services is transport-independent time. In particular, the time spent on organizing transportation (in the absence of transport, inability to find the right places during loading, etc.). Sometimes non-transportation time is considered more important than transportation time.

To assess the effectiveness of the delivery time of the cargo, it is advisable to make a calculation using the formulas (1), (4) above. Consider a mathematical model for assessing the efficiency of delivery times when using 3PL and 4PL logistics services:

$>$ Travel time - 36 hours

$>$ Start time of unloading containers - 13:00.

$>$ Unloading time 22:00

$>$ time of loading and unloading - 33 hours;

$>$ Unloading intensity -12.78 containers per hour.

Therefore, we are considering different options for the delivery time (Table 7). 
Table 7. Options for transport and logistics operations.

\begin{tabular}{|c|c|c|}
\hline Options & Calculation formulas for variants & $(7)$ \\
\hline$A$ & $\mathrm{~T}_{\mathrm{A}}=\mathrm{T}_{1-3}+\mathrm{T}_{3}+\mathrm{T}_{3-4}+\mathrm{T}_{4}+\mathrm{T}_{4-6}+\mathrm{T}_{6}$ & $(8)$ \\
\hline $\mathrm{B}$ & $\mathrm{T}_{\mathrm{B}}=\mathrm{T}_{1-2}+\mathrm{T}_{2}+\mathrm{T}_{2-3}+\mathrm{T}_{3}+\mathrm{T}_{3-4}+\mathrm{T}_{4}+\mathrm{T}_{4-6}+\mathrm{T}_{6}$ & $(9)$ \\
\hline $\mathrm{C}$ & $\mathrm{T}_{\mathrm{C}}=\mathrm{T}_{1-3}+\mathrm{T}_{3}+\mathrm{T}_{3-4}+\mathrm{T}_{4}+\mathrm{T}_{4-5}+\mathrm{T}_{5}+\mathrm{T}_{5-6}+\mathrm{T}_{6}$ & $(10)$ \\
\hline $\mathrm{D}$ & $\mathrm{T}_{\mathrm{D}}=\mathrm{T}_{1-2}+\mathrm{T}_{2}+\mathrm{T}_{2-3}+\mathrm{T}_{3}+\mathrm{T}_{3-4}+\mathrm{T}_{4-5}+\mathrm{T}_{5}+\mathrm{T}_{5-6}+\mathrm{T}_{6}$ & (
\end{tabular}

Here:

1 - point of departure; 2 - raid; 3 - vehicle inspection; 4 - customs; 5 - transfer of cargo to another type of transport; 6 - cargo receiving point.

$\mathrm{T} \_\mathrm{i}$ - this is the time it takes to deliver goods in the 1-2-3-4-5-6 chain as shown in Figure 3.2.

On the basis of formulas (7-10), in all cases, the delivery time was calculated for options A, B, C, D. Data on the standardization of the delivery time of goods and the calculation of their results are presented in Table 8 .

Table 8. Results of calculating options for delivery times.

\begin{tabular}{|c|c|c|c|c|c|c|c|c|c|c|c|c|c|c|}
\hline 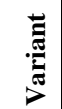 & $\mathrm{T}_{v a r}$ & $\mathrm{~T}_{1-2}$ & $\mathrm{~T}_{2}$ & $\mathrm{~T}_{2-3}$ & $\mathrm{~T}_{1-3}$ & $\mathrm{~T}_{3}$ & $\mathrm{~T}_{3-4}$ & $\mathrm{~T}_{4}$ & $\mathrm{~T}_{4-5}$ & $\mathrm{~T}_{4-6}$ & $\mathrm{~T}_{5}$ & $\mathrm{~T}_{5-6}$ & $\mathrm{~T}_{6}$ & $\sum \mathrm{T}_{\boldsymbol{i}}$ \\
\hline \multirow{3}{*}{$\mathrm{T}_{\mathrm{A}}$} & $\mathrm{T}_{\mathrm{A} 1}$ & - & - & - & 46 & 4 & 0.2 & 1.5 & - & 40 & - & - & 2 & 93.7 \\
\hline & $\mathrm{T}_{\mathrm{A} 2}$ & - & - & - & 41 & 9 & 0.3 & 5.55 & - & 42 & - & - & 3 & 100.8 \\
\hline & $\mathrm{T}_{\mathrm{A} 3}$ & - & - & - & 52 & 6 & 0.4 & 5 & - & 44 & - & - & 4 & 111.4 \\
\hline \multirow{3}{*}{$\mathrm{T}_{\mathrm{B}}$} & $\mathrm{T}_{\mathrm{B} 1}$ & 33 & 4 & - & - & 8 & 0.3 & 2.5 & - & 35 & - & - & 3 & 85.8 \\
\hline & $\mathrm{T}_{\mathrm{B} 2}$ & 40 & 2 & 1 & - & 9 & 0.2 & 1.5 & - & 30 & - & - & 4 & 87.7 \\
\hline & $\mathrm{T}_{\mathrm{B} 3}$ & 35 & 3 & - & - & 9 & 0.3 & 4.5 & - & 36 & - & - & 3 & 90.8 \\
\hline \multirow{3}{*}{$\mathrm{T}_{\mathrm{C}}$} & $\mathrm{T}_{\mathrm{C} 1}$ & - & - & - & 41 & 8 & 0.4 & 2.5 & 0.2 & - & 58 & 20.5 & 3 & 133.6 \\
\hline & $\mathrm{T}_{\mathrm{C} 2}$ & - & - & - & 46 & 6 & 0.4 & 3.5 & 0.4 & - & 76 & 25.5 & 4 & 162.8 \\
\hline & $\mathrm{T}_{\mathrm{C} 3}$ & - & - & - & 38 & 7 & 0.3 & 4 & 0.3 & - & 106 & 30.5 & 3 & 189.1 \\
\hline \multirow{3}{*}{$\mathrm{T}_{\boldsymbol{D}}$} & $\mathrm{T}_{D 1}$ & 45 & 3 & 1 & - & 8 & 0.4 & 3.5 & 0.4 & - & 96 & 31.5 & 2 & 189.8 \\
\hline & $\mathrm{T}_{D 2}$ & 46 & 2 & - & - & 9 & 0.4 & 4.5 & 0.4 & - & 146 & 35.5 & 3 & 246.8 \\
\hline & $\mathrm{T}_{D 3}$ & 43 & 3 & 1 & - & 7 & 0.3 & 4 & 0.3 & - & 180 & 31.5 & 3 & 273.1 \\
\hline
\end{tabular}

According to the results of calculations in Table 8 , the delivery times of goods for options A, B, C, D were determined in the form of a diagram (Figure 1). According to the analysis, options $\mathrm{A}$ and $\mathrm{B}$ are more acceptable than options $\mathrm{C}$ and $\mathrm{D}$ due to the less time required.

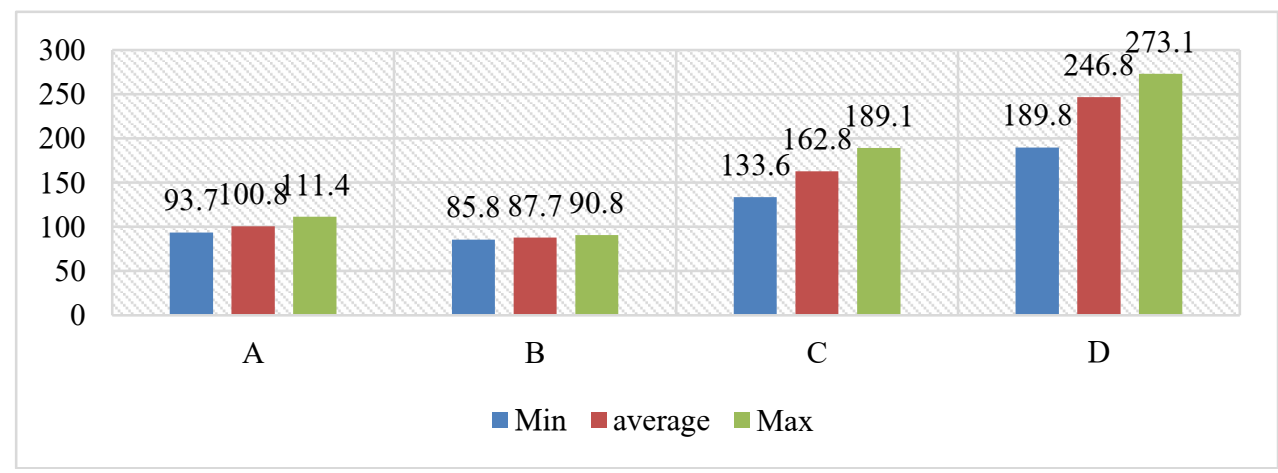

Fig. 1. Delivery time of choice. 
According to the results of table 8 , the efficiency of delivery times was assessed using the transformation ratio for options $\mathrm{A}, \mathrm{B}, \mathrm{C}, \mathrm{D}$ (table 9).

Table 9. Efficiency of delivery times for options A, B, C, D.

\begin{tabular}{|c|c|c|}
\hline Options & The effectiveness of the compared options & \\
\hline A & $\begin{array}{c}\mathrm{K}_{\mathrm{A} 2}=1+\frac{\sum \mathrm{T}_{\mathrm{A} 2}-\sum \mathrm{T}_{\mathrm{A} 1}}{\sum \mathrm{T}_{\mathrm{A} 1}}=1+\frac{100,8-93,7}{93,7}=1,07 \\
\delta_{\mathrm{A} 2}=\left(\mathrm{K}_{\mathrm{A} 2}-1\right) * 100 \%=7 \% \\
\mathrm{~K}_{\mathrm{A} 3}=1+\frac{\sum \mathrm{T}_{\mathrm{A} 3}-\sum \mathrm{T}_{\mathrm{A} 1}}{\sum \mathrm{T}_{\mathrm{A} 1}}=1+\frac{111,4-93,7}{93,7}=1,18 \\
\delta_{\mathrm{A} 3}=\left(\mathrm{K}_{\mathrm{A} 3}-1\right) * 100 \%=18 \%\end{array}$ & (11) \\
\hline B & $\begin{array}{c}\mathrm{K}_{\mathrm{B} 2}=1+\frac{\sum \mathrm{T}_{\mathrm{B} 2}-\sum \mathrm{T}_{\mathrm{B} 1}}{\sum \mathrm{T}_{\mathrm{B} 1}}=1+\frac{87,7-85,8}{85,8}=1,02 \\
\delta_{\mathrm{B} 2}=\left(\mathrm{K}_{\mathrm{B} 2}-1\right) * 100 \%=2 \% \\
\mathrm{~K}_{\mathrm{B} 3}=1+\frac{\sum \mathrm{T}_{\mathrm{B} 3}-\sum \mathrm{T}_{\mathrm{B} 1}}{\sum \mathrm{T}_{\mathrm{B} 1}}=1+\frac{90,8-85,8}{85,8}=1,05 \\
\delta_{\mathrm{B} 3}=\left(\mathrm{K}_{\mathrm{B} 3}-1\right) * 100 \%=5 \%\end{array}$ & (12) \\
\hline $\mathrm{C}$ & $\begin{array}{c}\mathrm{K}_{\mathrm{C} 2}=1+\frac{\sum \mathrm{T}_{\mathrm{C} 2}-\sum \mathrm{T}_{\mathrm{C} 1}}{\sum \mathrm{T}_{\mathrm{C} 1}}=1+\frac{162,8-133,6}{133,6}=1,21 \\
\delta_{\mathrm{C} 2}=\left(\mathrm{K}_{\mathrm{C} 2}-1\right) * 100 \%=21 \% \\
\mathrm{~K}_{\mathrm{C} 3}=1+\frac{\sum \mathrm{T}_{\mathrm{C} 3}-\sum \mathrm{T}_{\mathrm{C} 1}}{\sum \mathrm{T}_{\mathrm{C} 1}}=1+\frac{189,1-133,6}{133,6}=1,41 \\
\delta_{\mathrm{C} 3}=\left(\mathrm{K}_{\mathrm{C} 3}-1\right) * 100 \%=41 \%\end{array}$ & (13) \\
\hline D & $\begin{array}{c}\mathrm{K}_{D 2}=1+\frac{\sum \mathrm{T}_{D 2}-\sum \mathrm{T}_{D 1}}{\sum \mathrm{T}_{D 1}}=1+\frac{246,8-189,8}{189,8}=1,30 \\
\delta_{D 2}=\left(\mathrm{K}_{D 2}-1\right) * 100 \%=30 \% \\
\mathrm{~K}_{D 3}=1+\frac{\sum \mathrm{T}_{D 3}-\sum \mathrm{T}_{D 1}}{\sum \mathrm{T}_{D 1}}=1+\frac{273,1-189,8}{189,4}=1,43 \\
\delta_{D 3}=\left(\mathrm{K}_{D 3}-1\right) * 100 \%=43 \%\end{array}$ & (14) \\
\hline
\end{tabular}

Thus, according to the results of calculations, the transformation ratio, which shows that transport and logistics operations take more time, makes it possible to evaluate the effectiveness of the compared options for the delivery of goods. Accordingly, options A and $\mathrm{B}$ provide a $25 \%$ reduction in delivery time compared to options $\mathrm{C}$ and $\mathrm{D}$.

This result can be achieved through effective management of the cargo delivery process. Below we will consider an economic and mathematical model for assessing the management efficiency of an integrated transport and logistics system [11,12].

Assessing the effectiveness of integrated transport and logistics management is a rather complex process. Therefore, it is recommended to define the main criteria for assessing the effectiveness of management and express the relationship between them using a mathematical function. Therefore, the main criteria for the operation of the system were:

- $\quad$ cargo weight "M", in tons; 
- $\quad$ distance traveled "L" in kilometers;

- Delivery time "T", in hours;

- Transportation and logistics costs in X amounts

The relationship between these criteria was expressed on the basis of the following economic and mathematical model:

$$
\mathrm{I}_{\mathrm{K}}=\mathrm{M}^{x} * L^{y} * T^{z} * X^{f}
$$

Where I_k is an indicator of the economic assessment of integrated transport and logistics activities;

$\mathrm{x}, \mathrm{y}, \mathrm{z}, \mathrm{f}$ - general estimates, which represent clear and interpretable analytical results within the following limits:

$$
-3.0 \leq x, y, z, f \leq 3.0
$$

$\mathrm{x}, \mathrm{y}, \mathrm{z}, \mathrm{f}$ This ratio can be viewed as an indicator that can be applied to any type of transport in general. Therefore, when $\mathrm{x}=0, \mathrm{y}=1, \mathrm{z}=0, \mathrm{f}=0$, the following relation arises:

$$
\mathrm{I} \_\mathrm{k}=\mathrm{M}^{\wedge} 0 * \mathrm{~L}^{\wedge} 1 * \mathrm{~T}^{\wedge} 0 * \mathrm{X}^{\wedge} 0=\mathrm{km} \text {, distance }
$$

When $\mathrm{x}=0, \mathrm{y}=1, \mathrm{z}=-1, \mathrm{f}=0$, the following equation is:

$$
\mathrm{I} \_\mathrm{k}=\mathrm{M}^{\wedge} 0 * \mathrm{~L}^{\wedge} 1 * \mathrm{~T}^{\wedge}(-1) * \mathrm{X}^{\wedge} 0=\mathrm{km} / \mathrm{h} \text {, travel speed }
$$

The economic and mathematical model for assessing the management efficiency of an integrated transport and logistics system is the relationship between transport quality management and logistics, taking into account performance indicators [13, 14]. The indicators of the management quality of the integrated transport and logistics system affect the performance indicators, and the economic and mathematical model for assessing the management efficiency of the integrated transport and logistics system is characterized by the following indicators:

$$
\begin{gathered}
\mathrm{C}_{j}=f\left(\mathrm{~K}_{b c}, I\right), \\
x_{\text {imin }} \leq x_{i} \leq x_{\text {imax }} \\
Y=\varphi_{i}\left(I_{i}\right) \leftrightarrow e x t
\end{gathered}
$$

Here:

$C_{i}$ - economic efficiency of integrated transport and logistics activities;

$K_{b c}$ - coefficient that determines the level of management efficiency;

$x_{i}$ - organizational and economic indicators;

$x_{\text {imin }}, x_{\text {imax }}-$ maximum and minimum values of organizational and economic indicators;

$Y-$ multifactorial function affecting efficiency.

Thus, the effective management process of an integrated transport and logistics system based on formulas (3.20-3.26) is expressed by the following function.

$$
Y=0.243 * x_{1}+0.192 * x_{2}+0.17 * x_{3}+0.109 * x_{4}
$$

Thus, the concept of clear deadlines, which allows to minimize delivery times, an economic and mathematical model for organizing a logistics company at the 3PL and 4PL levels, a target function that allows assessing the effectiveness of system management, effective integration of activities, reduce the cost of logistics and system management we think. 


\section{Conclusion}

In short, one of the main elements of the efficiency of the transport and logistics system in JSC "Uzbekistan Temir Yullari" is to minimize logistics costs, reduce the time required to fulfill orders of service consumers $[15,16]$. Uzbekistan Temir Yullari JSC confirmed that the use of modern logistics technologies and integrated logistics concepts "Ishikawa diagram", "value-added flow map" and "real-time" (JIT) reduces delivery time by $25 \%$. The proposed methods and recommendations to improve the management of integrated transport and logistics system to Develop short-term and long-term strategies for the effective management of integrated transport and logistics system, the modernization of the system, coordination and integration with business partners, quality customer service, increasing the competitiveness of logistics service providers while increasing the efficiency of management activities integrated transport and logistics system.

\section{Reference}

1. The World Bank: World Development Indicators, http: //data.worldbank.org/indicator

2. Decree of the President of the Republic of Uzbekistan PF-4947 dated February 7, 2017 "On the Strategy of Actions for the Further Development of the Republic of Uzbekistan", www.lex.uz.

3. Appeal of the President of the Republic of Uzbekistan to the Supreme Council of 24.01.2020

4. A.J. Venables, Journal of Transport Economics and Policy 41, 173-188 (2007)

5. I.V. Kovrijnyx, Analysis of the effectiveness of management in organizations (AF SibAGS, Barnul, 2016)

6. J.S. Fayzullayev, Asian Journal of Technology \& Management Research (AJTMR) 9(2) (2019) http://www.ajtmr.com/papers/Vol9Issue2/Vol9Iss2_P9.pdf

7. A.A. Zohidov, Providing an effective mechanism for managing the transport system of Central Asia (Tashkent, 2018)

8. S. Frederick Starr, Filat Yildiz, Martina Reiser et. al., The New Silk roads: Transport and trade in Greater Central Asia. Monograph Central Asia Caucasus institute \& Silk Road Studies Program (Johns Hopkins University-SAIS, Washington, D.C., 2007)

9. G.A. Golts, Transport and macroeconomics of Russia for three centuries. Materials $X$ international (thirteenth Yekaterinburg) scientific and practical conference (2004)

10. J.S. Fayzullayev, Bulletin of Science and Pracrice Science Journal 5(4), 345-352 (2018) DOI:10.5281/zenodo.1147072

11. J.S. Fayzullayev, XLVII International correspondence scientific and practical conference "International scientific review of the problems and prospects of modern science and education» (Boston, USA, 2018) https://scientificconference.com/images/PDF/2018/49/International-scientific-review-7-49-ISBN.pdf

12. J.S. Fayzullayev, International scientific-practical conference "Strategy of action of the Republic of Uzbekistan: macroeconomic stability, investment activity and prospects for innovative development" (Tashkent, 2018)

13. J. Fayzullayev, Archive of Scientific Research 1(3) https://tsue.scienceweb.uz/index.php/archive/article/view/3892

14. J.S. Fayzullayev, Asian Journal of Technology \& Management Research (AJTMR) 9(2), 62-65 (2019) https://saarj.com/wp-content/uploads/SAJMMR-JULY-2020FULL-JOURNAL.pdf 
15. J.S. Fayzullayev, Asian Journal of Technology \& Management Research (AJTMR) 2 (2019) http://ajtmr.com/papers/SplIss2/SplIss2_8.pdf

16. J.S. Fayzullaev, Proceedings of Global Technovation 2 nd International Multidisciplinary Scientific Conference (London, U.K., 2020) https://conferencepublication.com 